\title{
S5ynthesis
}

International Scientific Conference of IT and Business-Related Research

\section{ISTRAŽIVANJE PODATAKA: HR TRENDOVI U 2015.}

\author{
DATA MINING: HR TRENDS IN 2015.
}

\author{
Jelena Đorđević Boljanović, Gordana Dobrijević, Vladimir Džamić, Filip Đoković \\ Univerzitet Singidunum, Danijelova 32, Beograd, Srbija
}

\begin{abstract}
Apstrakt:
Proučavanje trendova omogućava razumevanje promena i njihovog značaja, kako za poslovno okruženje, samu organizaciju i pojedince unutar nje. Imajući to u vidu, ovaj rad se prevashodno bavi ispitivanjem funkcije menadžmenta ljudskih resursa i njegove uloge u savremenom, promenjivom, poslovnom okruženju, kao i mogućnošću da adekvatno odgovori na očekivane i aktuelne trendove u ovoj oblasti. Ovaj rad ima za cilj da pruži odgovor na pitanje da li i u kojoj meri menadžment ljudskih resursa može da se prilagodi datim trendovima, kao i da ukaže na poželjne politike i prakse koje bi trebalo primenjivati kako bi se eliminisale potencijalne opasnosti i pretnje iz okruženja i stvorile nove poslovne mogućnosti i šanse.
\end{abstract}

\section{Ključne reči:}

trendovi, menadžment ljudskih resursa.

\section{UVOD}

Ako pođemo od već ustaljene premise da su trendovi podaci iz budućnosti, onda možemo zaključiti da je izučavanje trendova značajno bez obzira na to čime se naša organizacija bavi ili koliko zaposlenih ima. Ono što jeste važno naglasiti u vezi sa trendovima jeste da njihovo izučavanje omogućava organizacijama da budu proaktivne. To podrazumeva njihovu sposobnost ne samo da se prilagođavaju promenama koje nužno, svakodnevno i konstantno nastaju u poslovnom okruženju, već i da svojim pravim poslovnim odlukama menjaju poslovno okruženje, samu organizaciju i svoje zaposlene. Govoreći o trendovima u smislu negovanja konstantnog poslovnog razvoja, kao imperativa poslovanja u savremenom okruženju, postoje 4 osnovna razloga zašto je istraživanje trendova važno (Nixon, 2014):

1. Jasnoća. Značaj izučavanja trenda je da može da pomogne u stvaranju ponovljivog i održivog sistema metoda koji će omogućiti identifikaciju prilika i pravaca poslovnog razvoja. Trend reflektuje ono što se tek nazire u društvu u smislu ponašanja i stavova, ali još uvek nije imenovano.

2. Provocira novo. Proučavanje spoljnih provokatora podstiče eksperimentisanje i istraživanje novih ideja. Ovde je bitna i perspektiva različitih ljudi koji mogu da pomognu da se vide stvari u novom svetlu.

3. Samosvest. Što se više bavimo istraživanjem trendova, postajemo više svesni svog poslovnog pravca - delimično zato što ćemo biti primorani da ga artikulišemo i definišemo koliko je to što radimo slično ili različito od pravaca koje smo otkrili.

\section{Abstract:}

The analysis of trends provides better understanding of the incurred changes and their significance for the overall business environment, the organization itself and individuals within it. Having this in mind, this paper places an emphasis on the managerial function of human resource management and its role in the contemporary ever-changing business environment. The authors shall attempt to determine whether and to what extent the human resource management can respond to the ongoing or expected trends in this field, as well as to identify the policies and practices they should implement in order to eliminate all the threats and challenges from the environment and turn them into new business opportunities.

\section{Key words:}

trends, human resource management.

4. Osvežavanje planova. Trendovi se koriste kako bi se podstaklo razmišljanje. Nije ideja definisati da li je trend pravi ili pogrešan. Bitno je otkriti neiskorišćenu priliku ili biti inspirisan na primenu ideje na neki određeni brend ili posao. Dakle, u pitanju je potencijalna primena trenda na poslovanje i razmatranje da li je to dobro ili loše za naše klijente.

Dakle, ako o izučavanju trendova govorimo kao o načinu širenja novih ideja, predviđanja implikacija ovih ideja u budućnosti, načinu da ne razmišljamo samo o prošlim dešavanjima i podacima već da u svetlu budućih dešavanja zamislimo našu uslugu ili proizvod, onda se kao jedini način istinskog razmišljanja čini smatranje relevantnim ne samo sadašnjosti, već i budućnosti. Ovakav način razmišljanja, inspirisan novim načinom sagledavanja budućnosti, smatramo, imperativ je savremenog poslovanja.

\section{TRENDOVI U MENADŽMENTU LJUDSKIH RESURSA}

Pozicioniranje menadžmenta ljudskih resursa kao ključne funkcije u organizaciji, nameće potrebu odgovora na potrebe optimizacije i reinženjeringa na svim organizacionim nivoima, potrebe upravljanja talentima i razvoja zaposlenih (Mathis \& Jackson, 2011), ali i potrebu stalnih istraživanja trendova u ovoj oblasti. Istraživanja su brojna i zaokupljaju pažnju stručne, kako akademske javnosti, tako i praktičara iz ove oblasti. Cilj ovog rada je da prezentujemo neka od ovih istraživanja i da ih uporedimo, s jedne strane sa očekivanjima zaposlenih širom sveta u vezi sa poslom i radom, kao i sa samim menadžmen- 
tom ljudskih resursa, odnosno da pokušamo da damo odgovor na pitanje koje karaktersitike funkcija menadžmenta ljudskih resursa treba da ima da bi u budućnosti odgovorila zahtevima savremenog tržišta rada.

U navedenom smislu, najpre navodimo predviđanja koja navodi časopis Forbs. Naime, prema Forbsu ključni HR trendovi u 2015. godini će biti sledeći (Schawbel, 2014):

1. Kompanije zapošljavaju pripadnike $Z$ generacije (rođeni između 1994. i 2010.) kao stažiste. Dok većina kompanija maksimalno ulaže napore u razumevanje generacije $\mathrm{Y}$, neke kompanije već investiraju u dolazeću generaciju Z. Najstariji pripadnici ove generacije su na završnim godinama koledža. To svakako ne smeta kompanijama poput Deloitte, Microsoft, Rackspace and Lockheed Martin, da iz reda srednjoškolaca regrutuju polaznike svojih programa za stažiranje. Kompanije kao što su Facebook, LinkedIn i VMware uveliko plaćaju hiljade dolara srednjoškolcima kako bi stažirali kod njih. Dva su glavna razloga za navedeno: 1) kompanije se trude da zatvore postojeći jaz u veštinama i 2) kompanije se trude da budu konkurentne u borbi za talentima, a stvaranje svesti o brendu veoma rano, dakle kod srednjoškolaca, pravo je vreme za to.

2. Generacija Y preuzima lidersku ulogu. Zahvaljujući odlasku pripadnika starijih generacija iz organizacija, pripadnici generacije Y (rođeni između 1980. i 2000. godine) zauzimaju rukovodeće pozicije u kompanijama. Prema nekim predviđanjima ovaj trend se nastavlja i u narednom periodu. Pitanje koje ovakav trend povlači sa sobom svakako je pitanje njihovog iskustva i spremnosti za ovakve pozicije.

3. Iskrenost postaje veoma cenjena osobina kod lidera. Kompanije će početi sa sveobuhvatnijom transparentnošću već od ove godine, upravo na zahtev mlađih generacija. Lideri će morati ne samo da budu dobri u inspirisanju i edukaciji zaposlenih, već će morati da budu u stanju da usade poverenje kod svojih sledbenika kroz iskrenost. Ljudi žele da rade pod rukovodstvom lidera koji otvoreno govore o tome šta kompanija radi, koji je njen pravac u budućnosti i redovno pružaju iskrene povratne informacije.

4. Jaz u veštinama nastavlja da se širi. Ovo je svakako najveći izazov koji se nalazi pred HR specijalistima. Sve više poslodavaca se žali da ne može naći kandidate odgovarajućih veština, dok, s druge strane, nastavni planovi i programi obrazovnih ustanova ne retko ne odgovara zahtevima tržišta.

5. Kontinuirana potraga za poslom. Osnovno pitanje sa kojim će kompanije morati da se nose je pitanje zadržavanja zaposlenih. Zaposleni prolaze kroz proces kontinuiranog traženja posla i po tom pitanju se nikada neće smiriti. Ovo se dešava zbog toga što tehnologija omogućava lakše pronalaženje novih radnih mesta i pronalaženje novih talenata. Jedino što kompanije mogu da urade da bi zadržali svoje zaposlene jeste stvaranje superiorne prijateljske radne kulture u kojoj su uključeni u rad i dobijaju privilegije.

6. Zapošljavanje i traženje posla preko mobilnih telefona. Sve je veći naglasak na mobilnom regrutovanju. Preko $83 \%$ onih koji traže posao trenutno koriste pametne telefone za traženje radnih mesta, a $45 \%$ aktivnih kandidata prijavilo se na prijavu za posao preko svog mobilnog uređaja. Kompanije će morati da počnu optimizaciju svojih sajtova, pa čak i kreiranje mobilnih aplikacija, a na zahteve i molbe aplikanata za posao.
7. Socijalni mediji se koriste kako bi se privukli i zadržali talenti. Sve više će biti vidljivi blogovi i postovi kompanija. Da bi se kompanija izdvojila kao poslodavac, moraće da postavlja postove koji su u vezi sa radnom kulturom, koje bi kasnije delili njeni zaposleni. Prema istraživanjima 58\% ljudi bi radije želelo da radi u kompaniji koja koristi društvene medije, a u istom slučaju za preko $20 \%$ njih je veća verovatnoća da će ostati da rade u svojim preduzećima.

8. Uspešno planiranje sukcesije postaje prioritet. Planiranje sukcesije će biti glavna briga za preduzeća, posebno kod povlačenja velikog broja baby boomers-a. Jedan od načina planiranja sukcesije jeste zadržavanje nekih odlazećih radnika na platnom spisku. Oko 65\% radnika planira da radi za platu kada se budu penzionisali. Sve češće će se videti kompanije koje zadržavaju svoje starije radnike u cilju prenošenja znanja na mlađe kolege.

9. Žene i dalje preuzimaju vodeće pozicije na radnom mestu. Nova istraživanja pokazuju da finansijski najuspešnije kompanije imaju 37\% žena među svojim liderima.

10. Sve više ljudi pravi iskorak iz tradicionalnih puteva u svojoj karijeri. Sve više će biti honoraraca, privremenih radnika i konsultanata jer je to mnogo isplativije za kompanije. Nedavna studija Elance-oDesk pokazuje da 53 miliona Amerikanaca radi honorarno, što čini 34\% američke radne snage.

Vrlo zanimljivo i vrlo opsežno istraživanje sproveo je PWC pod nazivom The future of work: A journey to 2022, koje je sprovedeno 2014. godine (PWC, 2014) na 10000 ispitanika iz Kine, Indije, Nemačke, Velike Britanije i SAD, kao i na $480 \mathrm{HR}$ profesionalaca iz navedenih zemalja. Cilj istraživanja je utvrditi kako zaposleni vide budućnost posla i šta posao znači za njih. Navodimo najinteresantnije rezultate istraživanja:

- $66 \%$ ispitanika vide budućnost posla kao svet pun mogućnosti uz veru da će biti uspešni u njemu,

- 53\% ispitanika smatra tehnološki napredak glavnim uzročnikom transformacije posla u narednih 5 do 10 godina,

- $44 \%$ ispitanika smatra da je najvažnija stvar u vezi sa poslom sigurnost posla,

- 64\% ispitanika smatra da će tehnologija unaprediti njihove perspektive u vezi sa poslom,

- $65 \%$ ispitanika širom sveta želi da radi u organizacijama sa jakom društvenom odgovornošću,

- $29 \%$ isptanika želi od posla preuzimanje kontrole nad svojom karijerom i poslom koji obavljaju,

- $46 \%$ HR specijalista očekuje da najmanje $20 \%$ radne snage budu angažovani po ugovoru ili kao privremeno zaposleni,

- 2 od 5 ispitanika veruju da tradicionalnog zapošljavanja neće biti u budućnosti. Umesto toga, ljudi će imati sopstvene „brendove“ i prodavaće svoje veštine onima kojima je to potrebno,

- $31 \%$ HR profesionalaca grade svoju strategiju za privlačenje i zadržavanje talenata zapošljavanjem ljudi različitih veština na pristupačan način, na ad hoc osnovi.

Još jedno zanimljivo istraživanje je sprovedeno od strane Center for Effective Organizations (Boudreau et al., 2014) u konzorcijumu sastavljenom od 11 velikih kompanija: Citrix Systems Inc.; Electronic Arts Inc.; Gap Inc.; Lockheed Martin Corp.; Mattel Inc.; Rockwell Automation; Royal Bank of Canada; Sony Pictures Entertainment; Unilever; UPS Inc.; The Walt Disney Co. Dvadeset do trideset HR profesionalaca iz svake od navedenih kompanija učestvovalo je u konzorcijumu. Cilj istraživanja su 
bili trendovi globalizacije, generacijskih razlika, održivosti, socijalnih medija, personalnih tehnologija, masovne kastomizacije, inovacija, big data i gamification. U tabeli koja sledi identifikovana su četiri trenda koja su već prisutna (sa leve strane) i trendovi koji se naziru na horizontu (desna kolona tabele):

\begin{tabular}{|c|c|}
\hline $\begin{array}{l}\text { Globalizacija: } \\
\text { Integracija svetske } \\
\text { ekonomije kroz razmenu } \\
\text { roba, usluga i kapitala }\end{array}$ & $\begin{array}{l}\text { Personalna tehnologija: } \\
\text { mobilne platforme kao što su } \\
\text { pametni telefoni, laptop i tablet } \\
\text { računari, buduće tehnologije kao } \\
\text { što su Google naočare i aplika- } \\
\text { cije koje ih podržavaju, koje bez } \\
\text { problema i konstantno povezuju } \\
\text { ljude i Web sadržaje }\end{array}$ \\
\hline $\begin{array}{l}\text { Generacijske raznovr- } \\
\text { snosti: } \\
\text { Prisustvo mnogih različi- } \\
\text { tih starosnih grupa među } \\
\text { radnicima, građanima i } \\
\text { potrošačima. }\end{array}$ & $\begin{array}{l}\text { Masovna kastomizacija: } \\
\text { Kombinacija masovne proizvod- } \\
\text { nje sa kastomizacijom za različite } \\
\text { individualne potrošače ili grupe } \\
\text { kako bi se povezalo zadovoljenje } \\
\text { potreba ljudi sa efektivnošću i efi- } \\
\text { kasnošću masovne proizvodnje. }\end{array}$ \\
\hline $\begin{array}{l}\text { Održivost: } \\
\text { Rešavanje potreba da- } \\
\text { našnjice bez ugrožavanja } \\
\text { mogućnosti budućih } \\
\text { generacija da zadovolje } \\
\text { svoje potrebe. }\end{array}$ & $\begin{array}{l}\text { Otvorena inovacija: } \\
\text { Priliv i odliv znanja kako bi se } \\
\text { povećale inovacije, uključujući } \\
\text { korisnika inovacije, inovativne } \\
\text { ekosisteme i nadmetanje u inova- } \\
\text { cijama. }\end{array}$ \\
\hline \multirow[t]{2}{*}{$\begin{array}{l}\text { Društveni mediji: } \\
\text { Online mreže i dvosmer- } \\
\text { ni komunikacioni kanali } \\
\text { koji povezuju korisnike } \\
\text { u virtuelnom svetu, } \\
\text { uspostavljajući nove od- } \\
\text { nose koji proširuju mreže } \\
\text { korisnika i olakšavaju } \\
\text { učešće korisnika u inte- } \\
\text { rakcijama i razmenama. }\end{array}$} & $\begin{array}{l}\text { Big data: } \\
\text { Podaci koji su preveliki, previše } \\
\text { nestrukturirani ili previše različiti } \\
\text { da bi bili čuvani ili analizirani na } \\
\text { uobičajeni način, uz uobičajene } \\
\text { metode, procese i alate. }\end{array}$ \\
\hline & $\begin{array}{l}\text { Gamification: } \\
\text { Primena mehanizma i principa } \\
\text { igara na situacije koje nisu igra } \\
\text { kako bi se izvršila motivacija i } \\
\text { promena ponašanja. }\end{array}$ \\
\hline
\end{tabular}

Tabela 1. Prisutni i budući trendovi u menadžmentu ljudskih resursa (Boudreau et al., 2014)

\section{ODGOVOR NA TRENDOVE}

$\mathrm{Na}$ osnovu analize rezultata navedenih istraživanja, trendovi koji su neminovni u budućnosti razvoja funkcije menadžmenta ljudskih resursa, svode se na četiri grupe već uveliko prisutnih promena (Đorđević Boljanović \& Pavić, 2011):

1. Demografske promene - razlike u generacijama zaposlenih moraju se uzeti u obzir prilikom koncipiranja funkcije menadžmenta ljudskih resursa. Takođe, radnu snagu karakteriše sve starija radna snaga i povećanje broja penzionisanih radnika. Zapravo, osnovni problem je što ne postoji dovoljan broj mlađih zaposlenih koji će zameniti sve rastući broj penzionisanih pripadnika „baby boom“ generacije. Sadašnja aktivna radna snaga, fokus svojih interesovanja pomera sa posla na porodicu ili postiže balans između ove dve sfere interesovanja. Otuda i teškoća pred kojom se nalaze menadžeri ljudskih resursa kako bi postigli navedeni balans, ali u uslovima zahtevnog konkurentskog okruženja. Raznovrsnost radne snage, kako po pitanju rase, tako i po pitanju etničke i nacionalne pripadnosti, sve je prisutnija. Povećava se prisustvo žena na tržištu rada. Još jedna karakteristika savremene radne snage jeste povećanje radnika zaposlenih sa nepunim radnim vremenom, radnika koji poslove obavljaju po ugovoru, radnika koji rade više poslova ili onih koji rade na određeno vreme.

2. Tehnološki razvoj više nije trend, već svakodnevnica. Promene ove vrste dovode do tražnje za visokokvalifikovanom radnom snagom. Zato se od odeljenja za ljudske resurse zahteva, ne samo dobro osmišljen postupak zapošljavanja, već i organizovanje kvalitetnih treninga i obuka (Noe et al., 2007). U tom smilsu, tehnologija se već uveliko uključuje u sve faze i aktivnosti menadžmenta ljudskih resursa. Tako govorimo o prijavljivanju potencijalnih kandidata za određeno radno mesto i njihovom regrutovanju putem interneta; procesu selekcije koji ne samo da proverava veštine i znanja iz oblasti informacionih tehnologija, nego podrazumeva i korišćenje mnogih tehnologija i internet metoda i alata u samoj selekciji (npr. on-line testovi i sl.); metodama obuke i treninga zasnovanim na veb tehnologiji i, naravno načinima i metodama komunikacije u samoj organizaciji, pa i u vezi sa poslovima i aktivnostima menadžmenta ljudskih resursa.

3. Globalizacija. Pod globalizacijom podrazumevamo širenje poslovanja organizacija na inostrana tržišta. Globalizacija nameće savremenom menadžmentu brisanje granica među državama, a sobom nosi i izraženiju konkurenciju, ne samo među kompanijama, nego i među pojedincima, dok se mobilnost radne snage drastično povećava. Veća globalizacija podrazumeva veću konkurenciju, a veća konkurencija od savremenih kompanija zahteva da budu „prve u klasi“ - da smanje troškove, da učine zaposlene produktivnijim i da proizvode bolje i što jeftinije. I kompanije i pojedinci, treba da rade više i pametnije nego što su to činile bez globalizacije (Dessler, 2011). Globalizacija sobom donosi i potrebu za mnogo većim radom, ali i manju sigurnost posla. Pronalaženje i angažovanje zaposlenih van granica matične zemlje ( $J o b$ offshoring), jedna je od sve prisutnijih pojava u savremenom poslovanju velikih kompanija

4. Promene u prirodi posla. Pre svega, potrebno je naglasiti povećanje visoko tehnološki profilisanih poslova i radnih mesta. Još jedna promena u prirodi posla čiji smo svedoci, svakako jeste i povećanje poslova i radnih mesta koji se bave pružanjem usluga, u odnosu na prozvodne poslove. Ovde treba dodati i neminovnu fleksibilnost koja je ušla u sve pore savremene organizacije rada.

Radi razmatranja načina na koje menadžment ljudskih resursa treba da odgovori na gore objašnjene trendove, bitno je još jednom apostrofirati definiciju menadžmenta ljudskih resursa kao strategijski i koherentni pristup upravljanju najvrednijom imovinom u organizaciji, ljudima, koji radeći u njoj, individualno ili kolektivno, doprinose postizanju njenih ciljeva (Armstrong, 2006), iz koje se kao logičan nameće zaključak o važnosti i značaju menadžmenta ljudskih resursa za čitavu organizaciju i zaposlene u njoj. S druge strane, održiva konkurentska prednost može proisteći samo iz veština, iskustva i kreativnosti zaposlenih. Upravljanje ljudskim resursima, da bi se kreativna i nova budućnost pretvorila u realnost i omogućila organizaciji ono što nazivamo održivom konkurentskom prednošću, je svakako najvažniji menadžment izazov u 21. veku. U skladu sa ranije pomenutom potrebom istraživanja trendova u poslovnom 
okruženju, vremenom se iskristalisalo nekoliko ključnih zadataka koji bi trebalo da postanu svakodnevnica menadžmenta ljudskih resursa, a radi iskorišćavanja onog najboljeg u trendovima koji dolaze, odnosno radi pretvaranja svih potencijalnih opasnosti koje trendovi nužno sobom nose u poslovne šanse koje organizacije treba da iskorsite. Navodimo ključne među njima (Henderson, 2008):

- Usvajanje prakse „visokih performansi“ (HPWP - high - performance work practices) koja ima za cilj postizanje boljih individualnih, timskih i organizacionih performansi na taj način što se povećava posvećenost zaposlenih i njihova uključenost u poboljšanje rezultata rada.

- Insistiranje na fleksibilnoj organizaciji oslonjenoj na ključne zaposlene sa većim investiranjem u ljudske resurse.

- Organizacija posla na mikro nivou - timski rad, obuka, razvijanje novih veština, grupno rešavanje problema, porast funkcionalne fleksibilnosti, učešča zaposlenih u dizajniranju radnih procesa i deljenje korisnog i specifičnog znanja.

- Sofisticirane prakse u regrutovanju i selekciji.

- Odnosi zaposlenih u pozitivnom, inspirativnom i motivišućem okruženju.

- Menadžment promene: „jedina konstanta je promena“ postaje kliše, ali oslikava realnost - konkurentno globalna ekonomija i kontinuirani tehnološki razvoj.

- „Organizacija koja uči“ definisana kao organizacija koja ohrabruje učenje na svim nivoima i na taj način brine o kontinuiranim promenama sebe same.

- Menadžment znanja kao korišćenje ideja i iskustva zaposlenih, klijenata i poslovnih partnera, radi unapređivanja organizacionih performansi.

- Liderstvo koje inicira i reaguje na promene i postiže visoke performanse rada.

Jedino na ovakav, proaktivan način moguće je menadžment ljudskih resursa posmatrati kao proaktivnu menadžersku funkciju koja može, s jedne strane sagledati sve snage, ali i slabosti svoje organizacije, a sa druge iskoristiti ono što je najbolje u njoj, a to je svakako znanje i sposobnosti svojih zaposlenih i usmeriti ga optimalnom brzinom ka budućnosti.

\section{REZIME}

$\mathrm{Na}$ osnovu analize rezultata navedenih istraživanja, kao osnovni zaključak nameće se obaveza menadžmenta ljudskih resursa da proaktivno, u skladu sa potrebama tržišta rada pristupi analizi svih pitanja i rešavanju svih problema koji su u vezi sa upravljanjem ljudskim resursima. Zapravo, ono što jeste nužnost, to je preispitivanje uloge ove menadžment funkcije. Da li je i u kojoj meri proaktivna? Da li učestvuje ne samo u implementaciji, već i u stvaranju organizacione strategije? Da li je strategijski partner u organizaciji? Da li zaposlene posmatra kao ljudski kapital? Da li zaposlene u organizaciji posmatra kao talente?

Da bi odgovor bio pozitivan na navedena pitanja i da bi menadžment ljudskih resursa mogao da sagleda značaj predviđanja trendova o kome smo govorili na početku rada, potrebno je da $\mathrm{u}$ organizacijama zauzima poziciju strategijskog partnera u organizaciji. To je jedini način integracije poslovne strategije sa ljudima koji će implementirati tu strategiju. To dalje znači sa strategije menadžmenta ljudskih resursa treba da budu u direktnoj vezi sa poslovnom strategijom kao deo menadžerskog razmišljanja, planiranja i akcije (York, 2010), a u cilju stvaranja održive konkurentske prednosti. Ako tome dodamo već razmatrana i istraživanjem utvrđena očekivanja koja ljudi širom sveta imaju u vezi sa poslom i radom u godinama koje slede, a koja se odnose na iščekivanje mogućnosti koje su pred njima uz veru da će u tome biti uspešni, onda su mogućnosti neiscrpne u budućnosti koja je tek započela.

\section{LITERATURA}

Armstrong, M. (2006). A Handbook of Human Resource Management Practice, 10th edition, Kogan Page, London

Dessler, G. (2011). Human Resource Management. New Jersay: Pearson.

Đorđević Boljanović, J., \& Pavić, Ž. (2011). Osnove menadžmenta ljudskih resursa. Beograd: Univerzitet Singidunum,

Henderson, I. (2008) Human Resource Management for MBA Students. London: Chatered Institute of Personnel and Development.

Boudreau, J., Gibson, C. \& Ziskin, I. (2014). What Is the Future of HR? Dostupno na http://www.workforce.com/ articles/20179-what-is-the-future-of-hr, preuzeto 3.2.2015.

Mathis, R. L., \& Jackson, J. H. (2011). Human Resource management, thirteenth edition. USA: South Western Cengage Learning.

Natalie Nixon (2014). 4 Reasons Why Trend Research Is Not Spitting In The Wind: Jump Start Your Innovation Process. Dostupno na http://www.inc.com/natalie-nixon/4-reasonswhy-trend-research-is-not-spitting-in-the-wind-jumpstart-your-innovat.html, preuzeto 3.2.2015.

Noe, R. A., Hollenbeck, J. R., Gerhart, B., \& Wright, P. M. (2007). Fundamentals of Human Resource management. Boston: Mc Graw Hill.

PWC (2014). The future of work A journey to 2022. Dostupno na http://www.pwc.com/gx/en/managing-tomorrows-people/ future-of-work/journey-to-2022.jhtml

Schawbel, D. (2014). 10 Workplace Trends for 2015. Dostupno na http://www.forbes.com/sites/danschawbel/2013/10/24/ the-top-10-workplace-trends-for-2014/, preuzeto 3.2.2015.

York, K. M. (2010). Applied Human Resource management. Los Angeles: Sage Publications. 